\begin{abstract}
АННОТАЦИЯ
Задачи повышения международной конкурентоспособности и экспорта российского образования в рамках национальных Зприоритетов развития неразрывно связаны с необходимостью создания благоприятной среды для адаптации иностранных студентов на основе экосистемных и стейкхолдерных подходов. Формирование интегральной и многоаспектной модели межкультурной адаптационной экосистемы для российских университетов и других образовательных организаций должно происходить при полном признании ценностей внешней и внутренней интернационализации во всех видах деятельности с целью формирования долгосрочных ключевых компетенций. Модель межкультурной адаптационной экосистемы должна стать матричным и своего рода каркасным решением с точки зрения стратегического развития университетов в глобальном мире с учетом переосмысления и усложнения их миссии как социального института в международном партнерстве.

Статья предлагает комплексное ви́дение модели межкультурной адаптационной экосистемы университета с двумя контурами - внутренним и внешним. Внутренний контур включает в себя четыре составляющие: ценности, методики, процессы и структуры. Внешний контур межкультурной адаптационной экосистемы образовательной организации также состоит из четырех компонентов: внутрироссийских образовательных коллабораций, международного сотрудничества, взаимодействия с национальными и культурными сообществами и рекомендациями для органов власти.

Авторы предлагают подробный анализ факторов и приоритетов необходимых организационных изменений российских университетов в контексте задач стратегического развития у всех участников и стейкхолдеров образовательного процесса навыков межкультурной грамотности с дальнейшей трансформацией в компетенции культурного интеллекта.
\end{abstract}

\title{
КАЮЧЕВЫЕ САОВА:
}

студентоцентрированное обучение, иностранные студенты, культурная адаптация, адаптивная среда, межкультурные коммуникации, управление многообразием, кросс-культурные тренинги, интернационализация, тьютор, высшее образование, образовательная организация, университет.

\section{ААЯ ЦИТИРОВАНИЯ:}

Илькевич С.В., Приходько Л.В., Смит Н.Л. (2020). Модель межкультурной адаптационной экосистемы университетов как элемент стратегического развития // Стратегические решения и риск-менеджмент. Т. 11. № 3. С. 324-334. DOI: 10.17747/2618947X-2020-3-324-334.

Статья подготовлена по результатам исследований, выполненных за счет бюджетных средств, по государственному заданию Финансового университета в рамках научно-исследовательской работы «Разработка методов и механизмов межкультурной адаптации иностранных студентов». 


\title{
The model of the intercultural adaptation ecosystem of universities as an element of strategic development
}

\author{
S.V. Ilkevich ${ }^{1}$ \\ L.V. Prikhodko ${ }^{1}$ \\ N.L. Smith ${ }^{1}$
}

${ }^{1}$ Financial University under the Government of the Russian Federation

\begin{abstract}
The tasks of increasing the international competitiveness and export of Russian education within the framework of national development 1 priorities are inextricably linked with the need to create a favorable environment for the adaptation of international students based on ecosystem and stakeholder approaches. The development of an integral and multidimensional model of the Russian intercultural adaptation ecosystem for universities and other educational organizations should take place with full recognition of the values of external and internal internationalization in all activities in order to form long-term key competencies. The model of the intercultural adaptation ecosystem should become a matrix and, in a way, a framework solution from the point of view of the strategic development of universities in the global world, taking into account rethinking and sophistication of their mission as a social institution in global partnership.

The article offers a comprehensive vision of a model of an intercultural adaptation ecosystem of the educational organization with two contours - internal and external. The internal contour includes four components: values, practices, processes and structures. The external contour of the intercultural adaptation ecosystem of an educational organization also includes four components: inner Russian educational collaborations, international cooperation, interaction with national and cultural communities, and recommendations for authorities.

The authors offer a detailed analysis of the factors and priorities of the necessary organizational changes in Russian universities in the context of the tasks of intercultural literacy skills' strategic development for all participants and stakeholders of the educational process with further transformation into the competence of cultural intelligence.
\end{abstract}

\section{KEYWORDS:}

student-centered learning, international students, cultural adaptation, adaptive environment, intercultural communication, diversity management, cross-cultural trainings, internationalization, tutor, higher education, educational organization, university.

\section{FOR CITATION:}

Ilkevich S.V., Prikhodko L.V., Smith N.L. (2020). The model of the intercultural adaptation ecosystem of universities as an element of strategic development. Strategic Decision and Risk Management, 11(3), 324-334. DOI: 10.17747/2618-947X-2020-3-324-334. 


\section{1. ВВЕАЕНИЕ: ЭКОСИСТЕМНЫЙ ПОАХОА АЛЯ АААПТАЦИИ ИНОСТРАННЫХ СТУАЕНТОВ}

Текущее состояние развития интернационализации российского высшего образования требует критического переосмысления и усиления ценностной ориентации на более прогрессивные принципы. Наряду с успехами в улучшении обслуживания иностранных студентов в стандартных блоках процессов академических и административных служб университетов наблюдается не только недостаточное развитие, но и принципиальное ценностное недопонимание необходимости и продуктивности полноценного перехода к межкультурному взаимодействию и эффективному управлению многообразием как интегральной и сквозной функции образовательной системы в условиях расширения участия всех групп стейкхолдеров в формировании культуры образовательных организаций [Straker, 2016].

На современном этапе российские университеты находятся на сравнительно ранних стадиях формирования задач стратегического развития в глобальном мире с учетом переосмысления и усложнения их миссии как социального института в глобальном партнерстве [Pherali, Lewis, 2019]. В качестве дискуссионного тезиса можно говорить о том, что усредненное понимание всей широты миссии университетов в рамках нарастающей интернационализации и взаимозависимости у российских образовательных организаций по центральным тезисам и приоритетам традиционно запаздывает примерно на десятилетие по сравнению с лидерами экспорта образования. Эта проблема в какой-то степени, несомненно, «материалистична» (в смысле «бытие определяет сознание»): попытки российских университетов выйти за пределы традиционных экспортных рынков - СНГ и Африки - пока малорезультативны. И потому легко замкнуться в рамках самоизоляционной ментальности: «Мы не нужны, и нам никто не нужен». Но даже для того, чтобы не потерять рынки СНГ и Африки, как уже по большей части, пожалуй, безвозвратно потерян рынок Китая, нужно двигаться вперед. Задачи построения межкультурной адаптационной экосистемы на принципах функционального и инструментального понимания культурного интеллекта в образовательной среде будут становиться все более актуальными.

Понятие культурного интеллекта - Cultural Intelligence [Ott, Michailova, 2018] в качестве основополагающей категории в рамках интернационализации образования предполагает не приобретение знаний в результате обучения, а навык представителя иностранной культуры интерпретировать знаки другой культуры таким образом, как это сделали бы сами носители культуры [MacNab, Worthley, 2011], в отличие от инструментальных подходов, в рамках которых культурное многообразие в образовательной деятельности используется только для целей увеличения представительства учащихся с различным многообразным этническим и культурным происхождением [Moon, 2016].

Эффективные подходы адаптации и фасилитации индивидуализации обучения и образовательных достижений иностранных студентов с учетом разностороннего понимания их социальных и культурных потребностей и ценностей должны выстраиваться в виде экосистемного решения на основе стратегического ресурсного подхода к управлению образовательной организацией. Стратегический ресурсный подход предусматривает превращение ресурсов, которые направляются на развитие адаптации иностранных студентов, в устойчивые способности организации с последующим переходом способностей в отличительные компетенции и конкурентные преимущества [Delpechitre, Baker, 2017] на глобальном рынке образования на основе имплементации управления кросс-культурными различиями [ $\mathrm{Wu}$ et al., 2015].

Сквозной и всеобъемлющий подход к соблюдению принципов развития навыков межкультурного взаимодействия и коммуникаций со стороны образовательной, научной, социальной, воспитательной, неформальной работы с иностранными обучающимися, развития социальной сплоченности, повышения степени вовлеченности в командную работу и активную позицию в дискуссиях предусматривает создание полноценной среды благоприятствования (экосистемы), в основу которой целесообразно заложить восемь основных принципов совершенствования деятельности образовательной организации.

Стоит также оговориться, что в контексте настоящей публикации термины «университет» и «образовательная организация» используются как полностью взаимозаменяемые, так как в фокусе рассмотрения находятся прежде всего учреждения высшего образования. Однако важно отметить и то, что многие приоритеты, принципы и компоненты построения модели межкультурной адаптационной экосистемы довольно универсальны в целом для образовательного пространства: высшего, среднего специального и даже среднего.

\section{2. ПРИОРИТЕТЫ ААЯ ФОРМИРОВАНИЯ МЕЖКУАЬТУРНОЙ АААПТАЦИОННОЙ ЭКОСИСТЕМЫ УНИВЕРСИТЕТА}

Межкультурную адаптационную экосистему университета необходимо выстраивать на основе следующих прогрессивных приоритетов на стыке продуктивных трендов в образовании и межкультурном взаимодействии.

1. Развитие методических подходов и укрепление ценностей внутренней интернационализации образовательной организации, которые предусматривают постоянную интеграцию международных и межкультурных аспектов в формальную и неформальную деятельность для всех обучающихся в рамках домашнего (национального) образовательного пространства. Межкультурные компоненты включаются в перечень обязательных компетенций, формирующих как отдельные учебные дисциплины, так и образовательные программы в целом. Целенаправленное использование культурного многообразия в учебном процессе для обеспечения большей степени инклюзивности в обучении, преподавании и аттестации в рамках расширенного понимания методологии построения инклюзивных систем [Marginson, 2016], методических и методологических подходов в канве «от интер- 
национального к межкультурному» [Heyward, 2002].

2. Разработка методик индивидуального подхода к обучению и адаптации отдельного субъекта межкультурной коммуникации (иностранного обучающегося) в контексте принимающей национальной культуры, которая, в свою очередь, интегрирована в общее цивилизационное пространство, складывающееся под влиянием глобализации. Систематизация практических методик применения социокультурных технологий в процессе привлечения, обмена иностранными студентами и преподавателями, институционального и национального опыта адаптации, в том числе в зарубежных университетах-партнерах.

3. Повышение информационной открытости образовательной организации и преодоление барьеров межкультурных коммуникаций, включая развитие внутренней навигации в образовательной организации, комфортной и дружественной среды. Вовлечение в процесс интернационализации сотрудников всех направлений деятельности в вузе. Обеспечение целенаправленного взаимодействия с иностранными обучающимися.

4. Расширение инструментов и методик межкультурного взаимодействия в рамках формализации и регламентирования процессов и структур образовательной организации, в том числе для целей уменьшения как дистанции власти, так и культурной дистанции [Zhang, 2013].

5. Использование широкого инструментария вводного интенсивного адаптационного курса для иностранных студентов.
6. Внедрение системы мониторинга удовлетворенности реализацией образовательных программ. Развитие анкетирования иностранных обучающихся по параметрам адаптационной работы образовательной организации.

7. Формирование многоуровневой и целостной ценностно-компетентностной системы программ повышения квалификации в области адаптации иностранных студентов и тьюторской поддержки. Для преодоления коммуникативных барьеров субъекты межкультурной коммуникации расширяют и развивают межкультурную компетентность в контексте образовательного пространства.

8. Формирование института тьюторства как центрального кадрового звена в рамках системы гибких образовательных траекторий и фасилитации для иностранных студентов в контексте современных подходов и методик индивидуализации образования. Тьюторы должны понимать сложные социальные и культурные ценности иностранных студентов [Lochtie, 2016] и интегрировать ценности культуры наряду с индивидуальными ценностями учащихся в постановке своих целей, помогая учащимся определить, какие межкультурные и междисциплинарные навыки им необходимы для достижения целей обучения и преодоления стрессов, связанных с аккультурацией [Han et al., 2017].

Схема модели межкультурной адаптационной экосистемы университета с внутренним и внешним контурами представлена на рис. 1.

Рис. 1. Модель межкультурной адаптационной экосистемы университета: внутренний и внешний контуры

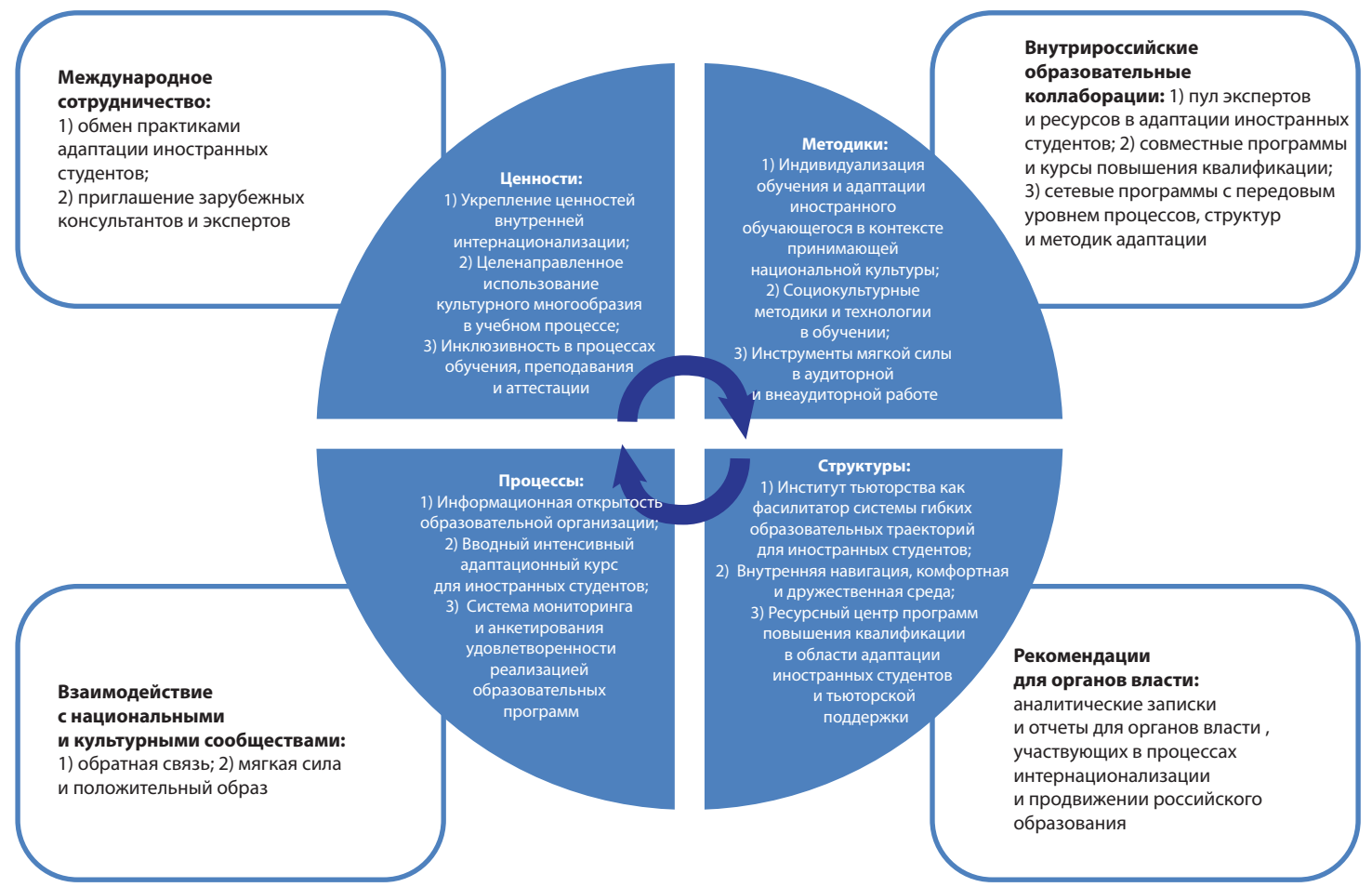




\section{3. ВНУТРЕННИЙ КОНТУР АААПТАЦИОННОЙ ЭКОСИСТЕМЫ УНИВЕРСИТЕТА}

Внутренний контур межкультурной адаптационной экосистемы университета включает в себя четыре составляющие: ценности, методики, процессы и структуры.

\section{1. ЦЕННОСТИ}

Первостепенным принципом межкультурного взаимодействия в поликультурной среде образовательной организации должны стать не столько профилактика, прогнозирование и предотвращение конфликтов, сколько выстраивание новой ценностной парадигмы и корпоративной культуры, которая будет способна создать благоприятную среду, адаптировать, привлекать и мотивировать иностранных студентов для обучения в РФ. Для этого требуется развитие гибких навыков и межкультурных компетенций у всех акторов образовательной организации, или, другими словами, необходимо наличие субъект-субъектной парадигмы отношений сторон и студентоцентрированный подход в работе всего персонала образовательной организации, предполагающий фокусироваться в профессиональной деятельности на потребности иностранных обучающихся.

С позиции формирования культурного интеллекта мотивационный аспект имеет первостепенное значение для качественных трансформаций образовательных организаций, так как необходимо систематическое и устойчивое повышение интереса, профессиональной и межкультурной осведомленности всех университетских служб, прямо или косвенно задействованных в создании дружелюбного академического и сервисного пространства для иностранных студентов.

Отправной точкой выстраивания новой ценностной модели в рамках адаптационной экосистемы образовательной организации являются иенности внутренней интернационализации, которые предусматривают интеграцию в образовательную среду приоритетов международного и межкультурного измерения в рамках как аудиторной, так и внеаудиторной деятельности образовательной организации.

Эта ценностная ориентация позволяет преодолевать проблемы ограниченных возможностей (в том числе в рамках географического распределения) международной мобильности. Даже при наличии в образовательной организации больших ресурсов и партнерских отношений по реализации программ и проектов по международной академической мобильности студентов и преподавателей этого недостаточно с точки зрения необходимости комплексно и в контексте прохождения всей образовательной программы формировать компетенции к работе в мультикультурном мире (в контексте международной конкуренции, в составах международных команд) у всех выпускников [Adair et al., 2013].

Безусловно, между двумя ценностями - внутренней интернационализации и проактивностью передовых участников международной мобильности - нет антагонизма и жесткой альтернативности. Речь, скорее, идет о том, что в рамках устоявшихся практик, а также параметров оценки эффективности деятельности образовательных организаций международная академическая мобильность оказывается более видимой, верифицируемой, измеримой, более учитываемой в качестве достижения и индикатора, тогда как ценности внутренней интернационализации оказываются более пренебрегаемыми в силу их более долгосрочных и менее осязаемых преимуществ.

Именно по этой причине необходимо ставить задачи правильной акцентуации и отражения ценностей внутренней интернационализации по всему спектру ее направлений: в рамках интернационализации административных служб и кампуса, отдельных структурных научно-образовательных подразделений, описаний и учебных планов основных образовательных программ и отдельных дисциплин. Стратегия внутренней интернационализации должна быть соотнесена со всеми стратегическими аспектами развития образовательной организации (миссией, целями и задачами, структурой, ключевыми показателями, партнерами) высшего учебного заведения в контексте усиления трендов интернационализации ее деятельности.

Целенаправленное использование культурного многообразия в дизайне образовательных программ и учебном процессе предполагает существенные трансформации в деятельности и поведенческих приоритетах студентов и преподавателей через переосмысление и изменение рутинных, привычных практик и подходов помимо содержания программ и отдельных предметов: новых методов, методик, приемов, инструментов в учебной и учебно-методической деятельности преподавателей, новых функций административных служб, учебных действий обучающихся, методик, форм и приемов контроля и оценивания результатов обучения.

Ценностная приоритизация в рамках компетентностного подхода предусматривает в качестве основных индикаторов компетенций способность будущих выпускников признавать важность и продуктивность межкультурного согласия, оценивать проблемы и профессиональные ситуации с различных точек зрения, демонстрировать понимание других культур как своей собственной культуры, понимать взаимосвязи между культурными и профессиональными традициями различных стран, оценивать последствия действий на местном уровне (на уровне сообществ) и для международных сообществ, уметь общаться с представителями другой культуры.

Она включает расширение способности к пониманию ограниченности своей собственной культуры и своего собственного языка и умения переключиться при встрече с другой культурой на другие, не только языковые, но и неязыковые нормы поведения, что не означает нивелирования собственной культуры, а наоборот, стимулирует рефлексию, создает понимание уникальности собственной культуры, самоидентификации в процессе интеракции с контрастами другой культуры.

\section{2. МЕТОАИКИ}

С точки зрения методического совершенствования параметров межкультурной адаптации образовательной организации особое значение имеет интернационализа- 
ция дисциплин в рамках приоритизации межкультурных аспектов рабочих программ, содержания, форм изучения, разработки материалов лекций и практических занятий, аудиторной работы со стороны студентов, критериев и подходов к контролю и оценивании.

Методико-методологические подходы к межкультурной коммуникации и адаптации в поликультурной среде в образовательных организациях на сегодня недостаточно разработаны, что отрицательно сказывается на осуществлении глубинной адаптации личности к существующему поликультурному пространству, а также не дает эффективно задействовать внутренние ресурсы. Таким образом, в условиях культурной неустойчивости образовательной организации необходимо разработать адекватный методический инструментарий для достижения гармонизации межкультурного взаимодействия между всеми акторами образовательного процесса.

Для многих преподавателей интернационализация дисциплин предполагает выход из зоны собственного профессионального комфорта, и в этой связи образовательным организациям нужно выстраивать систему методической поддержки: расширять международные компоненты учебных планов, развивать международное стратегическое партнерство, заниматься разработкой в полной мере интернационализированных рабочих программ дисциплин. Требуются изменения в подходах к дизайну учебных программ. Межкультурные компоненты должны быть включены в перечень обязательных компетенций, формируемых в рамках как отдельных учебных дисциплин, так и в образовательных программах в целом (например, включение во все программы отдельного модуля Diversity Management, как это применяется во многих зарубежных университетах). Интеграция международных компонентов при этом не должна быть ограничена факультативными дисциплинами или дисциплинами по выбору и не должна предназначаться только для отдельных групп обучающихся в рамках факультативных дисциплин или дисциплин по выбору.

Среди основных методических элементов усиления интернационализации и межкультурной адаптации в методической и учебно-методической деятельности образовательных организаций можно выделить следующие.

1. В содержании дисииплин: интернационализированные рабочие программы дисциплины, повышение важности проведения критического обзора и сопоставления отечественных и зарубежных источников, включение кейсов, примеров и иллюстраций из разных стран, культур, перспектив, заданий по сопоставительному анализу трендов или ситуации в других странах по сравнению с ситуациями в собственной стране.

2. В методике подготовки и проведения лекционных и практических занятий: расширение области применения поликультурных круглых столов, практикумов, иных форм внутригрупповых интерактивных занятий, проработка практических проектов с организациями, работающими над международными проектами; гостевые презентации лекторов с международным опытом с последующим обсуждением; ис- пользование проблематик и материалов от иностранных студентов.

3. В элементах работь студентов в рамках лекций и семинаров: расширение использования интерактивных форм, которые мотивируют местных и иностранных студентов на взаимодействие с представителями различных культур, обсуждение проблематик и тематик с иностранными студентами с целью углубления постановки задач в сравнительном аспекте, формулировка исследовательских задач на принципах сравнения локальных, национальных и международных практик.

4. В самостоятельной работе студентов: создание контекстов заданий для самостоятельной работы, которые мотивируют студентов изучать иностранные языки и аспекты кросс-культурной коммуникации, ценностные интерпретации и этические вопросы, включение задач, направленных на формирование межкультурных знаний, умений, отношений и поведения, или в области второго иностранного языка.

5. В фондах оценочных средств и методиках проведения текущего и промежуточного контроля: признание международных и межкультурных аспектов в учебных результатах, включая способности работать эффективно в мультикультурных и многоязычных контекстах при подготовке и представлении индивидуальных и групповых проектов; применение методик взаимопроверки с участием местных и иностранных студентов, иностранных преподавателей.

Таким образом, студенты любой программы, изучающие любой предмет, должны иметь представление о международной и межкультурной составляющей в своей предметной области благодаря встраиванию развития межкультурного знания, отношений и поведения в канву преподаваемого предмета. Студентам предлагается исследовать и критически анализировать реальность через линзы различных культурных и этнических групп.

Целенаправленное использование культурного многообразия в учебном процессе даст возможность обеспечить бо́льшую степень инклюзивности и студентоцентрированности в обучении и предоставлении услуг. Использование в качестве учебного ресурса культурного разнообразия студенческих групп позволит интегрировать опыт и знания не только иностранных студентов, но и студентов из разных регионов страны, из разных культур, разных слоев общества.

Важным методическим приоритетом является языковая поддержка иностранных обучающихся, которая может предусматривать введение дополнительных часов русского как иностранного в рамках основных образовательных программ (или по выбору вместо английского языка или других иностранных языков); обучение иностранных студентов в отдельных группах на первом курсе, где преподаватель учитывает уровень языковой подготовки учащихся и использует простой язык для объяснения материала, говорит медленно; разработку широкого спектра англоязычных программ для привлечения англоговорящего кластера иностранных студентов без обучения на подготовительном отделении. 


\section{3. ПРОЦЕССЫ}

Процессный подход в образовательной организации это прежде всего учет, совершенствование и целенаправленное использование элементов образовательного процесса и инфраструктурного контекста, включая информационную, ориентационную, презентационную, адаптационную составляющие и межкультурно-коммуникативный компонент.

В этой связи предлагается рассматривать внутреннюю среду образовательной организации не как моносреду, а как среду многомерную, включающую в себя различные субсреды функционального характера, которые можно классифицировать как академическую, информационную, социально-бытовую и этнокультурную среды. Поэтому важна разработка инновационной парадигмы адаптации, фокусирующейся на процессах адаптации иностранных студентов различных культур именно к многомерным средам образовательных организаций, так как проблемы коммуникации иностранных студентов в вузах проявляются не только на языковом уровне, но и в разрывах к требованиям к обучению и академическим стандартам, социально-бытовым аспектам, информационной доступности и культурно-этническим особенностям, устойчивым стереотипам и предрассудкам коммуницирующих субъектов.

Вводный интенсивный адаптационный курс для иностранных студентов включает проведение ориентационного инструктажа для вновь прибывающих иностранных студентов с участием служб образовательной организации (визово-регистрационных, учебных, общежития, финансовых и т.д.), организацию работы информационной стойки (Student Service Center) по фасилитации, сопровождению, навигации иностранных студентов в университетском пространстве, а также установку многоязычных указателей и обновление многоязычного сайта на основе принципов информационной открытости образовательной организачъии.

Модули могут быть разработаны и презентованы представителями различных сервисных отделов для вновь прибывающих иностранных студентов и студентов с миграционным прошлым (правила проживания в общежитиях, визы и вопросы регистрации; финансовые вопросы; знакомство с инфраструктурой: библиотекой, ключевыми офисами, внешней средой, например банками, аптеками, медицинскими услугами, охраной и культурными достопримечательностями). Дальнейшее наращивание полноценных внутриуниверситетских культурных связей должно основываться на улучшенном понимании потребностей в адаптации иностранных студентов, а также на признании их более широкого вклада в продуктивность и культурное разнообразие всей образовательной среды.

Основной методологический подход «от интернационального к межкультурному» требует методологии и разработки инструментов, применимых к качеству пребывания иностранных граждан в учебных заведениях, а именно к их адаптации в инокультурной среде и налаживанию эффективного межкультурного взаимодействия. В плане организационных изменений и предоставления институционального сервиса в измерении межкультурности важным элементом представляется развивать у всех участников образовательного процесса прежде всего межкультурную гра- мотность с дальнейшей трансформацией в навык культурного интеллекта.

Особенно важно непрерывное совериенствование системы мониторинга и анкетирования удовлетворенности реализачией образовательных программ. Отдельной компетенцией, на которую требуется обратить особое внимание, является владение методами интеграции в мультикультурные и многоязычные классы вновь прибывающих иностранных студентов. С целью эффективной интеграции важна разработка методологии для опроса потребностей иностранных студентов и обработки информации с целью создания базы данных по таким параметрам, как культурные, религиозные и этнические факторы. С тем чтобы понять и определить коммуникативные модели внутри определенной культурной группы, необходимо применить описательный и функциональный подходы, чтобы идентифицировать и измерить то, на чем базируются определенные представления и культурные ценности каждой отдельной группы.

\section{4. СТРУКТУРЫ}

Образовательное пространство неоднородно в силу разного уровня различных составляющих его сред. В первую очередь будущие студенты (иностранные абитуриенты) сталкиваются с информационной средой посредством поиска информации о правилах приема, программах обучения на сайте университетов. Вновь прибывающие студенты взаимодействуют сначала с социально-бытовой средой, где происходит приобщение их к правилам проживания и социально-культурным ценностям образовательной организации и внешней среды. Затем в процессе обучения иностранные студенты сталкиваются с новыми для них правилами и требованиями обучения и начинают взаимодействовать с преподавателями и студентами.

Ресурсный центр программ повышения квалификаиии в области адаптации иностранных студентов и тьюторской поддержки может оказаться высокоэффективным форматом для проведения тренингов для преподавателей по студентоцентрированному подходу и методам работы в многоязычном классе, в том числе включение в программы обучения студентов, в программы повышения квалификации преподавателей и административного персонала компонентов обучения культуре диалога.

Также эффективным инструментом в арсенале ресурсного центра может стать проведение тренингов повышения квалификации по студентоцентрированному подходу и обучению гибким навыкам (soft skills) не только преподавателей, но и административного персонала, работающего в контактной зоне [Rehg et al., 2012]. Взаимодействие с представителями других культур сопровождается большим психологическим напряжением, переживаниями и страхом. Основным способом преодоления этнокультурных барьеров коммуникации предлагается повышение межкультурной грамотности сотрудников, поскольку в межкультурном взаимодействии культурная образованность значительно отличается от простой «обученности». Развитие культурной грамотности индивида предполагает целенаправленное изменение субъекта, формирование у него необходимых знаний и навыков, способствующих его адекватной ориентации 
в практических ситуациях межкультурной коммуникации. Имеющееся знание в таком случае приобретает компетентностный характер и личностный смысл, поскольку их носитель вырабатывает личную экзистенциальную позицию.

Отмеченные новые подходы с точки зрения культурного интеллекта требуют, в свою очередь, изменений в системе повышения квалификации преподавателей и административных сотрудников, с тем чтобы обучить персонал контактной зоны фокусироваться в своей профессиональной деятельности на потребности иностранных студентов, так называемым студентоцентрированным навыкам ведения тренингов по обучению межкультурным компетенциям и курсов по методам преподавания в мультикультурных и многоязычных классах.

Институт тьюторства выступает в качестве фасилитатора системы гибких образовательных траекторий для иностранных студентов. Тьюторская поддержка по фасилитации в адаптации, навигации и выборе индивидуальных траекторий важна с точки зрения наличия в образовательной организации отдельной категории экспертов-консультантов (тьюторов), которые помогают с выбором предметов, практик, стажировок, дополнительных программ. Для того чтобы быть эффективными, тьюторы должны понимать сложные социальные и культурные ценности иностранных студентов.

Необходимо в части учебно-методической нагрузки тьюторов предусмотреть проведение методических советов по методикам консультаций и кураторства иностранных студентов, а также изучение и тренинги по методам преподавания в контекстах высокоинтерактивных мультикультурных и многоязычных аудиторий и задач обеспечения интеграции прибывающих иностранных студентов.

Внутренняя навигация, комфортная и дружественная среда необходимы для оптимизации условий пребывания иностранных студентов в кампусе, включая расселение в студенческом общежитии в мультикультурных группах по интернациональному принципу при обязательном наличии студента - носителя русского языка с целью стимуляции общения на русском языке, а также выделение дополнительных индивидуальных мест отдыха и подготовки к занятиям, пространств для коворкинга, комнат для совершения обрядов, молитв и уединения. Также эффективным является проведение цикла мероприятий, направленных на интернационализацию университетского сообщества, кросс-культурное взаимодействие, межнациональную и религиозную толерантность (например, национальных выставок, фестивалей культур и презентаций национальных кухонь), праздников национальных культур всех иностранных студентов образовательной организации.

Такие структуры, как центры предоставления услуг иностранным студентам (Student Service Points), могут быть направлены на оказание различных услуг по культурной и академической адаптации иностранных студентов, позволят оказывать содействие и консультирование иностранных студентов в выборе курсов, стажировок и программ обмена за рубежом, обеспечат дальнейшую индивидуализацию и вариативность обучения и укрепят академическую дисциплину. Навигация может включать пункты обслуживания студентов, двуязычные и много- язычные информационные стойки, навигационные дисплеи в залах и на этажах, мобильные приложения для иностранных посетителей, студентов и преподавателей. В центре обслуживания могут быть организованы широкие возможности для технологий и мер адаптации для иностранных студентов первого года обучения, например вечеринки, интенсивные двух- или трехнедельные брифинги иностранных студентов с участием всех соответствующих служб и отделов (оформление виз, обучение, общежития, финансы и т.д.), ознакомление с инфраструктурой.

\section{4. ВНЕШНИЙ КОНТУР АААПТАЦИОННОЙ ЭКОСИСТЕМЫ УНИВЕРСИТЕТА}

Внешний контур межкультурной адаптационной экосистемы образовательной организации включает в себя четыре составляющие: внутрироссийские образовательные коллаборации, международное сотрудничество, взаимодействие с национальными и культурными сообществами и рекомендации для органов власти.

Внутрироссийские образовательные коллаборации предусматривают большие возможности привлечения широкого пула экспертов и ресурсов в адаптации иностранных студентов, реализацию общими усилиями совместных программ и курсов повышения квалификации и на самом высоком уровне аккумулирования экспертизы - сетевых программ с передовым уровнем процессов, структур и методик адаптации.

Одним из продуктивных форматов взаимодействия в рамках коллабораций по совместному развитию системы адаптации иностранных студентов может стать разработка пилотной программы тренинга, повышения квалификации всех участников образовательного процесса для стимулирования сотрудников академических и неакадемических структур университетов, которая повышает межкультурные компетенции и гибкие навыки, ориентируясь на потребности иностранных студентов относительно направлений и тем проведения межкультурных тренингов для преподавательского и административного персонала, работающих в сфере межкультурной коммуникации, интеграционных, психологических и социальных аспектов взаимодействия с иностранными студентами, а также партнерами, в том числе в сфере делового общения и переписки.

В рамках служб международных связей образовательных организаций целесообразно создавать ресурсные центры с широким сетевым взаимодействием по изучению и внедрению лучших международных практик межкультурной адаптации студентов. На основе систематизации практических методик применения социокультурных технологий в процессе привлечения, обмена иностранными студентами и преподавателями, институционального и национального опытов адаптации ресурсные центры могут выступать элементами совершенствования и тиражирования методико-методологических инноваций межкультурного обучения и интеллекта для департаментов и кафедр, а также административных подразделений. 
Международное сотрудничество в совершенствовании адаптационной экосистемь образовательной организации может быть налажено через научно-практический и методический обмен практиками адаптации иностранных студентов, а также через регулярное приглашение зарубежных консультантов и экспертов. Особое значение имеют концептуальные и полевые совместные сравнительные международные исследования и интенсивный обмен опытом в сфере межкультурного взаимодействия. Инструменты сопоставления и гармонизации лучших международных и российских практик и идей в области интернационализации и адаптации, подходов и методов обучения в мультикультурных классах способствуют взаимному обогащению и разработке платформы, сфокусированной для преподавания и обсуждения, что может создать совместную эффективную коммуникационную среду и стать эффективным для всех участников обмена знаниями и опытом. В частности, целесообразно проведение для нужд целевых этнокультурных групп с возможностью организации на территории другой страны специализированных тренингов для целевых программ обучения иностранных сотрудников российских компаний с крупными операционными возможностями за рубежом. Таким образом, внутренние коммуникации университета станут более открытыми, демократичными, прозрачными, гибкими и трансформируемыми в отношении различных культур университетского сообщества.

В связи с этим представляется актуальной гармонизация российских и международных подходов к применению социокультурных технологий в процессе привлечения, обмена и адаптации иностранных студентов и преподавателей с использованием методологии сопоставления (компаративистики) и обобщения институционального и национального опытов адаптации в зарубежных университетах-партнерах с учетом особенностей последних в процедурах, методах и ценностных приоритетах.

Обратная связь в рамках взаимодействия с национальными и культурными сообществами может быть реализована через системы опросов и сбора данных для принятия мер по повышению эффективности межкультурных коммуникативных технологий. Такие элементы, как электронные анкеты для иностранных и отечественных студентов, платформы онлайн-опросов, предоставляют важные данные для принятия мер по улучшению культурной и академической адаптации. Разработка методики интервьюирования различных этнокультурных групп иностранных студентов и обработки информации с целью создания базы данных этнокультурных предпочтений при выборе российского образования может включать в себя репутацию национальной системы высшего образования на международном рынке образовательных услуг, возможности трудоустройства во время и после обучения, визовое и миграционное законодательство, плату за обучение, рейтинг и репутацию университета, качество образования, различные виды логистических удобств, экономические и политические связи, наличие или отсутствие двусторонних соглашений о признании документов об образовании.

Особенно многообещающей в этом отношении является разработка методологии учета возможностей и барье- ров в обеспечении оптимального формата межкультурного образования с целью преодоления стрессов иностранных студентов, связанных с аккультурацией. Другая сложная междисциплинарная задача - повышение личной удовлетворенности образовательными и внешкольными достижениями с учетом культурных, религиозных и национальных факторов [Blasko, 2015]. Для этого эффективным представляется также использование кластерного подхода. Применение процедуры кластеризации (кластерного анализа) дает возможность обоснованно группировать и лучше понимать схожие объекты, определять типичные и особенные элементы и характеристики для идентификации принадлежности иностранных студентов к определенным цивилизационным группам.

Другая важная грань взаимодействия с национальными и культурными сообществами - потенциирование и проецирование мягкой силь через высшее образование. Под мягкой силой понимается способность влиять на других и достигать национальных интересов посредством привлечения и убеждения, а не путем принуждения, военной силы или экономических санкций (обычно известных как жесткая сила).

Международное высшее образование широко признано как один из самых благородных и непротиворечивых инструментов концепции мягкой силы наряду с культурой и медициной, поскольку привлечение и убеждение через образование является наилучшим способом наладить межкультурный диалог и укрепить доверие, а доверие и сформировавшиеся симпатии могут в дальнейшем приносить дивиденды с точки зрения экономических и геополитических выгод, репутации и общей конкурентоспособности. Наиболее известные примеры мягкой силы в высшем образовании включают программу Фулбрайта, Британский совет, Германскую службу академических обменов, институты Конфуция, матрицу проектов Erasmus + Европейского союза.

Несомненно, за последние два десятилетия международное высшее образование кардинально изменилось. Границы пересекают не только студенты и ученые, но и программы, провайдеры, проекты. Сфера высшего образования характеризуется международными совместными исследовательскими проектами, двухнациональными (и более) университетами, многонациональными политическими сетями, программами глобальной мобильности, региональными центрами передового опыта и международными образовательными центрами. Признано, что в сильно взаимосвязанном и взаимозависимом мире, в котором мы живем, высшее образование является каналом для трансграничного потока и обмена людьми, знаниями, опытом, ценностями, инновациями, экономикой, технологиями и культурой.

Важно понимать еще более прогрессивную коннотацию и интерпретацию мягкой силы - принцип взаимной власти в рамках мягкой cuль, особенно актуальный в контексте образования. Эта концепция признает, что власть не обязательно должна быть так называемой игрой с нулевой суммой, она может иметь синергетические аспекты. Подход «взаимной власти» основан на соответствующих сильных сторонах высших учебных и исследовательских институтов страны и дает решения и преимущества для всех участни- 
ков. Ключевым моментом является то, что преимущества будут разными для разных участников. Это основано на реальности и «новой норме», согласно которой решение мировых проблем не может быть достигнуто одной страной в одиночку.

Инструменты мягкой силы образования работают только в долгосрочной перспективе. Университет мирового класса должен притягивать одаренную молодежь, квалифицированных преподавателей и научных сотрудников. Снижение концентрации талантов и исследовательских результатов ведет к утрате образовательной организацией геополитической миссии.

Альтернативой парадигме силы, будь то мягкая или взаимная сила, является концепция дипломатии, которая рассматривает переговоры как одну из своих основных опор. За последние два десятилетия дипломатия претерпела драматические изменения. Современная дипломатия признает, что процесс, ориентированный на государство, сосредоточенный прежде всего на министерствах иностранных дел и профессиональных дипломатах, больше не является адекватным. В него вовлечены множество новых участников, включая неправительственные организации, транснациональные корпорации, профессиональные ассоциации и экспертов по дипломатии. И высшее образование - один из этих ключевых игроков и инструментов современной дипломатии. Публичная и культурная дипломатия включает социальные сети, современные и традиционные формы искусства, архитектуру, язык и межкультурное обучение, академический обмен, спорт и другие средства как важные средства прямого взаимодействия с иностранной общественностью, а не только с правительством.

Аналитические записки и отчеты образовательных организаций для органов власти, участвующих в процессах интернационализации и продвижения российского образования, должны стать системой обратной связи и основой для совершенствования законодательства (включая подзаконные акты), а также аналитическим и экспертным базисом для тиражирования лучших практик в области комплексного выстраивания и совершенствования отдельных элементов межкультурной адаптационной экосистемы образовательных организаций.

Разработанные механизмы и инструменты могут быть реализованы для обеспечения качества и оценки результатов проводимых изменений в адаптации иностранных студентов в образовательных организациях РФ. Таким образом, будет внесен ценный вклад в управление культурными различиями в образовательном процессе и в моделирование адаптационной мультикультурной среды в российских вузах в рамках цикла интернационализации, который включает информационно-рекламные инструменты и набор, прием и зачисление, адаптацию и обучение, выпуск и развитие международных студенческих ассоциаций.

Разработка механизмов создания благоприятной среды в образовательных организациях и улучшение условий пребывания иностранных граждан в период обучения в России также являются приоритетными задачами проекта «Развитие экспортного потенциала российской системы образования».

\section{5. ЗАКАЮЧЕНИЕ}

Культурный интеллект и компетенции межкультурного взаимодействия должны стать для образовательных организаций стратегическим ресурсом во всех видах деятельности (научно-методологической, учебно-методической, проектной, воспитательной, международной) и одной из плоскостей для формирования отличительных компетенций и конкурентных преимуществ на глобальном рынке образования.

Ценностная и компетентностная приоритизация вовлечения в международные профессиональные практики всего студенческого контингента, преподавателей и административного состава, как показывает передовая зарубежная и российская практика, оказывается еще более важной в качестве экосистемного решения, нежели результативное развитие межкультурных компетенций и осведомленности контингента активных участников академической мобильности.

Как центральное звено экосистемы адаптации тьюторы должны интегрировать ценности социальной культуры наряду с индивидуальными ценностями учащихся в постановке своих целей и помочь последним определить, какие навыки им необходимы для достижения целей обучения. В результате иностранные студенты с помощью консультаций тьюторов должны лучше понимать, как формальные компоненты обучения могут быть наиболее взаимодополняющими и синергетическими в сочетании с неформальными.

Управление культурными различиями в образовательных средах может дать положительный эффект в преодолении барьеров, для чего предлагаются инструменты по обеспечению взаимодействия всех структурных уровней образовательной организации по администрированию, обучению и адаптации иностранных студентов.

\section{REFERENCES}

1. Adair W.L., Hideg I., Spence J.R. (2013) . The culturally intelligence team: The impact of team cultural intelligence on cultural heterogeneity on team shared values. Journal of Cross-Cultural Psychology, 44, 941-962.

2. Blasko M. (2015). Making the tacit explicit: Rethinking culturally inclusive pedagogy in international student academic adaptation. Pedagogy, Culture \& Society, 23(1), 85106. URL: https://doi.org/10.1080/14681366.2014.922120.

3. Delpechitre D., Baker D.S. (2017). Cross-cultural selling: Examining the importance of cultural intelligence in sales education. Journal of Marketing Education, 39(2), 94-108. URL: https://doi.org/10.1177/0273475317710060.

4. Han S., Pistole M.C., Caldwell J.M. (2017). Acculturative stress, parental and professor attachment, and college adjustment in Asian international students. Journal of Multicultural Counseling and Development, 45(2), 111-126. URL: https://doi.org/10.1002/jmcd.12068.

5. Heyward M. (2002). From international to intercultural Redefining the international school for a globalized world. Journal of Research in International Education, 1(1), 9-32.

6. Lochtie D. (2016). A 'special relationship' in higher education? What influence might the US higher education sector 
have in terms of support for international students in the UK? Perspectives: Policy and Practice in Higher Education, 20(2-3), 67-74.

7. MacNab B., Worthley R. (2011). Individual characteristics as predictors of cultural intelligence development: The relevance of self-efficacy. International Journal of Intercultural Relations. DOI: 10.1016/j.ijintrel.2010.12.00110.1016/j. ijintrel.2010.12.001.

8. Marginson S. (2016). The worldwide trend to high participation higher education: Dynamics of social stratification in inclusive systems. Higher Education, 72(4), 413-434. URL: https://doi.org/10.1007/s10734-016-0016-x

9. Rennie J. Moon (2016). Internationalisation without cultural diversity? Higher Education in Korea, Comparative Education, 52(1), 91-108. DOI: 10.1080/03050068.2015.1125679.

10. Ott D.L., Michailova S. (2018). Cultural intelligence: A review and new research avenues. International Journal of Management Reviews, 20, 99-119. DOI: 10.1111/ ijmr.12118.

\section{ИНФОРМАЦИЯ ОБ АВТОРАХ}

\section{Сергей Викторович Илькевич}

Кандидат экономических наук, доцент Департамента менеджмента и инноваций ФГОБУ ВО «Финансовый университет при Правительстве Российской Федерации».

Область научных интересов: городская мобильность, транспортные системы, инновации и бизнес-модели, международный бизнес, менеджмент в туризме, сервисный менеджмент, цифровая трансформация отраслей, экономика совместного пользования, экономика впечатлений, интернационализация образования.

E-mail: SVIlkevich@fa.ru

\section{Лилия Васильевна Приходько}

Кандидат технических наук, доцент Департамента менеджмента и инноваций, начальник управления международного сотрудничества ФГОБУ ВО «Финансовый университет при Правительстве Российской Федерации».

Область научных интересов: интернационализация образования, академическая мобильность, международные образовательные программы, электронное обучение, переподготовка кадров, развитие образовательного пространства, управление человеческими ресурсами, управление персоналом.

E-mail: LVPrikhodko@fa.ru

\section{Наталья Львовна Смит}

Старший преподаватель Департамента менеджмента и инноваций, главный специалист управления международного сотрудничества ФГОБУ ВО «Финансовый университет при Правительстве Российской Федерации».

Область научных интересов: управление изменениями и лидерство, международные образовательные программы, академическая мобильность, валидация неформального образования, компаративистика в образовании.

E-mail: NLSmit@fa.ru
11. Pherali T., Lewis A. (2019). Developing global partnerships in higher education for peacebuilding: A strategy for pathways to impact. Higher Educaion, 78, 729-744. URL: https://doi.org/10.1007/s10734-019-00367-7.

12. Rehg M.T., Gundlach M.J., Grigorian R.A. (2012). Examining the influence of cross-cultural training on cultural intelligence and specific self-efficacy. Cross Cultural Management: An International Journal, 19, 215-232.

13. Straker J. (2016). International student participation in higher education: Changing the focus from "international students" to "participation". Journal of Studies in International Education, 20(4), 299-318.

14. Wu H.-P., Garza E., Guzman N. (2015). International stusents' challenge and adjustment to college. Educational Research International, art. ID 202753. URL: http://dx.doi. org/10.1155/2015/202753.

15. Zhang Y. (2013). Expatriate development for cross-cultural adjustment: Effects of cultural distance and cultural intelligence. Human Resource Development Review, 12, 177-199.

\section{ABOUT THE AUTHORS}

\section{Sergey V. Ilkevich}

Candidate of economic sciences, associate professor at the Department of Management and Innovations of Financial University under the Government of the Russian Federation.

Research interests: urban mobility, transport systems, innovation and business models, international business, tourism management, service management, digital transformation of industries, sharing economy, experience economy, internationalization of education.

E-mail: SVIlkevich@fa.ru

\section{Liliya V. Prikhodko}

Candidate of technical sciences, associate professor at the Department of Management and Innovations, head of the International Cooperation Department of Financial University under the Government of the Russian Federation.

Research interests: internationalization of education, academic mobility, international educational programs, e-learning, retraining of personnel, development of educational environment, human resource management, personnel management.

E-mail: LVPrikhodko@fa.ru

\section{Natalia L. Smith}

Senior lecturer at the Department of Management and Innovations, senior expert of the International Cooperation Department of Financial University under the Government of the Russian Federation.

Research interests: change management and leadership, international educational programs, academic mobility, validation of non-formal and informal learning, comparative studies in education.

E-mail: NLSmit@fa.ru 